\title{
PUSAT REKREASI DAN EDUKASI PEMBUDIDAYAAN MANGROVE
}

\author{
Tjan Venny Epilia ${ }^{1)}$, Budi A Sukada ${ }^{21}$ \\ 1)Program Studi S1 Arsitektur, Fakultas Teknik, Universitas Tarumanagara, vennyepilia@gmail.com \\ 2) Program Studi S1 Arsitektur, Fakultas Teknik, Universitas Tarumanagara, budisukada@yahoo.com
}

Masuk: 04-07-2021, revisi: 15-08-2021, diterima untuk diterbitkan: 23-10-2021

\begin{abstract}
Abstrak
Ekologi terbentuk oleh hubungan timbal balik antara makhluk hidup dengan lingkungannya membentuk suatu sistem yang teratur. Jika sistem tersebut mengalami perubahan akan mempengaruhi ekosistem lainnya dan membuat ekosistem terganggu. Arsitektur mengupayakan memperkecil gangguan yang terjadi pada ekosistem tersebut dengan membangun kualitas spasial dengan pemikiran ekologis. Keberadaan mangrove memiliki sejumlah manfaat terutama bagi masyarakat pesisir pantai. Tidak hanya masyarakat pesisir saja tetapi hutan mangrove menjadi 'rumah' bagi semua makhluk hidup yang hidup dan berkembangbiak disana. Namun tidak semua mangrove dalam kondisi baik, saat ini jumlah mangrove di Indonesia yang dalam kondisi rusak, terancam, dan terabaikan semakin bertambah tiap tahunnya. Penyebab utama terjadinya kerusakan hutan mangrove adalah konversi lahan yang beralihfungsi menjadi pemukiman, pertambakan, dan industri yang berdampak meningkatnya abrasi yang menyebabkan daratan semakin berkurang, rumah penduduk tergenang air, dan terancam tenggelam. Perlunya pemulihan dan pengelolaan mangrove sebagai antisipasi yang dapat dilakukan mencegah berkurangnya luasan mangrove. Salah satu cara melestarikan mangrove dengan memberikan edukasi bagi masyarakat untuk meningkatkan pengetahuan akan pentingnya peranan mangrove sehingga masyarakat dapat lebih peka dan peduli lingkungan. Dengan demikian masyarakat dapat mengelola mangrove dengan baik, menjaga dan melestarikan ekosistem mangrove untuk menjamin keberlanjutannya, serta meningkatkan kesadaran masyarakat terhadap lingkungan. Kegiatan edukasi dapat dikolaborasikan dengan kegiatan rekreasi yang mendukung konservasi alam dan mempertahankan mangrove yang ada saat ini. Dengan adanya sarana berupa pusat rekreasi dan edukasi pembudidayaan mangrove diharapkan dapat membantu menyelamatkan kerusakan mangrove sehingga dapat terlestarikan.
\end{abstract}

Kata kunci: Edukasi; Mangrove; Rekreasi

\begin{abstract}
Ecology is formed by the reciprocal relationship between living things and their environment forming an orderly system. Changes in one system will surely affect the others and disturbing the whole systems. Architecture seeks to minimize such a disturbance by building spatial quality with ecology in mind. The case of mangroves existence is taken due to its number of benefits, especially for coastal communities as well as mangrove forests being a home for all living things that stay and breed there. Sadly, not all mangroves are in good condition. Number of mangroves in Indonesia that are damaged, threatened, and neglected is increasing every year. The main cause of such destruction is conversion of land into settlements, agriculture, and industry. All of them give an impact on increasing abrasion, hence causing the land to decrease, flooding the residentials, and threating them to drown. There is an urgent need for mangrove restoration and management to prevent reduction of mangrove area. One way to do it is by providing education for the communities in concerned to increase their knowledge on the important role of mangroves so that they can be more care for such a kind of environment, being able to manage, protect and preserve its ecosystem so as to ensure its sustainability while increasing public awareness of the environment. The educational activities, on the other hand, can be collaborated with recreational activities that support nature conservation and maintain existing mangroves. With such facilities, it is hoped that mangroves can be preserved.
\end{abstract}

Keywords: Education; Mangrove; Recreation 


\section{PENDAHULUAN}

\section{Latar Belakang}

Indonesia sebagai negara kepulauan sangat membutuhkan keberadaan ekosistem mangrove. Hal ini disebabkan karena Indonesia memiliki garis pantai yang panjang sehingga beresiko mengalami abrasi lebih besar dibandingkan negara lain. Ekosistem mangrove berperan dalam melindungi pesisir pantai dari kerusakan alam yang disebabkan oleh abrasi atau pengikisan tanah oleh air laut.

Namun, degradasi mangrove semakin bertambah tiap tahun di Indonesia. Dalam 30 tahun terakhir Indonesia kehilangan 40\% hutan mangrove, sehingga pada tahun 2019 tersisa 3,31 juta hektar. Seluas 2 juta hektar hutan bakau Indonesia dalam kondisi baik dan 1,31 juta lainnya dalam kondisi rusak (Rahadian et al., 2019).

Kerusakan dari ekosistem mangrove ini sebagian besar disebabkan oleh faktor alam yaitu abrasi dan ulah manusia yang kurang peduli terhadap keseimbangan lingkungan. Degradasi mangrove yang disebabkan oleh ulah manusia antara lain penebangan liar, pengalihfungsian lahan menjadi pertambakan, dan pencemaran lingkungan, yang kurang mempertimbangkan dampak lingkungan merupakan ancaman bagi kelangsungan ekosistem mangrove.

Melihat kondisi hutan mangrove yang terancam, maka diperlukan upaya pelestarian hutan mangrove dengan membuat fasilitas rekreasi dan edukasi pembudidayaan mangrove. Rekreasi dan edukasi akan saling melengkapi dan berkesinambungan sehingga memberikan manfaat ganda bagi pengunjung. Rekreasi akan menambah daya tarik kawasan hutan mangrove dan edukasi akan menambah wawasan tentang hutan mangrove.

\section{Rumusan Permasalahan}

Kerusakan mangrove diharapkan dapat diatasi dengan merancang sebuah fasilitas rekreasi dan edukasi yang mengedukasi pengunjung supaya sadar akan pentingnya peranan mangrove dan kondisi mangrove saat ini. Melalui fasilitas rekreasi dan edukasi membuat program kegiatan yang dibutuhkan untuk melindungi dan melestarikan mangrove.

\section{Tujuan}

Perancangan ini bertujuan untuk mempertahankan dan menjaga keberlangsungan hutan mangrove yang ada saat ini dengan menciptakan fasilitas rekreasi dan edukasi sebagai upaya melindungi dan melestarikan mangrove. Dimana fasilitas tersebut memiliki program kegiatan yang merupakan solusi dari penyebab kerusakan mangrove.

\section{KAJIAN LITERATUR}

\section{Mangrove}

Mangrove adalah tumbuhan yang membentuk komunitas di daerah pasang surut yang mempunyai toleransi terhadap kadar garam air laut (Noor et al., 2012). Hutan mangrove merupakan sebagian wilayah ekosistem pantai yang mempunyai karakter unik dan memiliki potensi kekayaan hayati. Indonesia mempunyai hutan mangrove yang keberadaannya memberikan manfaat ekologi maupun sosial ekonomi bagi masyarakat sekitar. Ekosistem mangrove merupakan sumberdaya lahan basah pada wilayah pesisir, sistem penyangga kehidupan, dan kekayaan alam yang nilainya sangat tinggi.

Pada tahun 2019, luas mangrove di Indonesia sekitar 3,31 juta hektar. Namun tidak semua dalam kondisi baik, sekitar 1,31 juta hektar (38\%) mangrove dalam kondisi kritis dan rusak, sisanya masih dalam kondisi baik (Rahadian et al., 2019). Hal ini menyebabkan kelestarian mangrove tidak terjamin, berikut grafik luas mangrove di Indonesia berdasarkan hasil observasi data dan informasi luas mangrove dari berbagai sumber dan literatur. 


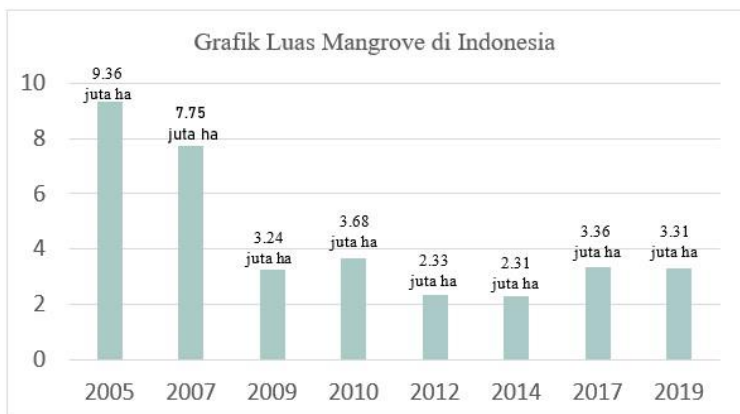

Gambar 1. Grafik Luas Mangrove di Indonesia Sumber: Rahadian et al., 2019

Kondisi hutan mangrove di Indonesia yang mengalami degradasi disebabkan oleh aktivitas manusia dan alam. Aktivitas manusia dalam hal pemanfaatan hutan mangrove untuk mencukupi kebutuhan manusia yang berakibat rusaknya hutan, antara lain:

- Penebangan liar Kerusakan hutan mangrove akibat penebangan liar tergolong rendah. Dulu penebangan hutan mangrove untuk membuat tambak udang windu. Sekarang penebangan dilakukan oleh masyarakat pesisir untuk kebutuhan memasak.

- Konversi lahan Alih fungsi lahan merupakan penyebab kerusakan hutan mangrove tergolong rendah. Berawal dari penebangan hutan mangrove yang berlebihan, lahan mangrove kemudian dikonversi menjadi pertambakan udang dan ikan.

- Pencemaran lingkungan

Kerusakan hutan mangrove yang disebabkan oleh pencemaran lingkungan tergolong rendah. Limbah pertanian, rumah tangga, dan industri menyumbang pencemaran yang merusak hutan mangrove. Sampah dan limbah industri dapat menutupi akar mangrove sehingga mengurangi kemampuan respirasi tumbuhan mangrove dan pada akhirnya menyebabkan kematian.

Sedangkan mangrove yang rusak oleh faktor alam yaitu:

- Abrasi

Kerusakan hutan mangrove akibat abrasi tergolong tinggi. Pemanasan global menyebabkan kenaikan permukaan air laut yang mengakibatkan kenaikan tinggi gelombang. Gelombang dan arus laut yang kuat mengganggu perakaran mangrove dan akhirnya mangrove rusak dan mati.

- Hama

Hama merupakan faktor penyebab yang relatif kecil. Hama yang menyerang mangrove antara lain serangga penggerek, ulat batang, tikus, kepiting, semut, kutu daun, dan siput (tergolong rendah). Serangan hama kepiting terhadap pohon mangrove yang paling tinggi. Kepiting menyerang bibit muda daun. Capitnya yang kuat merusak bibit muda yang batangnya masih sangat lunak. Serangan hama kepiting membuat tanaman bakau yang masih muda langsung mati.

\section{Rekreasi}

Rekreasi berasal dari bahasa latin yaitu re-creare atau recreation dalam bahasa Inggris, yang dapat diartikan yaitu membuat ulang. Rekreasi secara umum dapat diartikan sebagai kegiatan yang dilakukan untuk penyegaran kembali rohani dan jasmani diluar dari rutinitas yang dilakukan seseorang. Kegiatan yang dimaksud adalah pariwisata, olahraga, permainan dan hobi. Rekreasi dapat memperbarui ulang kondisi fisik dan jiwa seseorang sehingga rekreasi tidak hanya membuang-buang waktu. Rekreasi dianggap suatu penciptaan kembali jiwa dan tubuh seseorang yang terwujud karena menjauhkan diri dari tekanan rutinitas dalam kehidupan sehari-hari. Kegiatan rekreasi dapat membangun kembali aspek sosial, fisik, dan juga mental seseorang. Dengan rekreasi seseorang bisa mendapatkan 
kegembiraan, mempertahankan keseimbangan jiwa dan raga, meningkatkan kreativitas, dan mampu mengembangkan bakat yang dimilikinya.

\section{Edukasi}

Edukasi adalah proses pembelajaran yang dilakukan secara formal maupun informal untuk mewujudkan proses pembelajaran yang lebih baik, dengan tujuan mendidik, memberikan pengetahuan, dan mengembangkan potensi diri (Barus, 2015). Pengertian umum edukasi adalah usaha manusia untuk menumbuhkan dan mengembangkan potensi-potensi pembawaan jasmani maupun rohani sesuai dengan nilai-nilai yang ada di dalam masyarakat dan kebudayaan.

Edukasi memberikan banyak peluang untuk memperkenalkan kepada pengunjung tentang pentingnya perlindungan alam, mendorong masyarakat untuk mendukung dan mengembangkan upaya konservasi. Beriringan dengan aktivitas yang meningkatkan kesadaran masyarakat dan mengubah perilaku masyarakat tentang perlunya upaya konservasi sumber daya alam hayati dan ekosistemnya. Edukasi mengembangkan skema di mana pengunjung secara sukarela terlibat dalam kegiatan konservasi dan pengelolaan kawasan selama kunjungannya.

\section{Edutainment}

Edutainment terdiri atas 2 kata yaitu education yang berarti pendidikan dan entertainment yang berarti hiburan. Dari segi bahasa, edutainment adalah pendidikan yang menghibur atau menyenangkan. Pembelajaran yang menyenangkan biasanya dilakukan dengan humor, permainan, bermain peran, dan demonstrasi (Sutrisno, 2005). Dari segi terminologi edutainment sebagai bentuk hiburan yang dirancang untuk mendidik. Jadi edutainment bisa didefinisikan sebagai proses pembelajaran yang didesain dengan memadukan pendidikan dan hiburan secara harmonis, sehingga aktivitas pembelajaran berlangsung dengan menyenangkan.

\section{METODE}

Metode yang digunakan yaitu metode deskriptif dengan pendekatan regionalisme. Metode deskriptif dengan mengumpulkan dan menguraikan data sekunder yang didapatkan dari data statistik dan literatur yang berkaitan dengan ekosistem mangrove. Dari data tersebut dapat mengetahui penyebab degradasi mangrove yang kemudian menyusun strategi yang menjawab penyebab kerusakan mangrove.

Tahap selanjutnya adalah mendesain rancangan dengan menggunakan pendekatan regionalisme. Pendekatan regionalisme hadir pada suatu masa dimana arsitektur modern berusaha memutuskan diri dengan konteks masa lalu, baik dengan ciri maupun sifat-sifatnya. Pada periode setelahnya, muncul suatu paham idealisme yang bertujuan menemukan tautan antara paham modernisme yang berkembang dengan konteks daerah setempat sebagai akibat dari krisis identitas yang terjadi, salah satunya adalah regionalisme. Regionalisme dalam praktik arsitektur bukan dipandang sebagai sebuah langgam atau gaya, melainkan sebagai cara pandang atau cara berpikir berarsitektur. Pengaplikasian pendekatan arsitektur regionalisme pada desain bangunan, diantaranya:

- Tanggap terhadap sinar matahari melalui bukaan dan orientasi bangunan

- Penerapan material dan penyelesaian desain arsitektural

- Angin dan penghawaan alami dalam ruang

\section{DISKUSI DAN HASIL}

\section{Strategi Desain}

Berdasarkan penyebab rusaknya mangrove oleh penebangan liar, konversi lahan, pencemaran lingkungan, abrasi, dan hama, maka perlu dilakukan pemulihan dan pengelolaan hutan mangrove dengan cara:

- Penebangan liar dan konversi lahan

Pemulihan hutan mangrove melalui kegiatan penanaman kembali hutan mangrove dan penyuluhan pengelolaan mangrove. Penanaman mangrove dengan teknik REM (Riley Encased 
Methodology) dilakukan dimana buah atau tunas bakau ditanam langsung pada substrat yang sudah terpasang di batang bambu sebagai media pembungkusnya. Teknik REM dipakai karena lokasi penanaman berarus deras serta bergelombang tinggi.

Bibit bakau yang belum dapat berakar dengan baik dibantu dengan menggunakan bambu, untuk mengurangi guncangan bibit dari gelombang laut yang kuat. Bakau yang tumbuh dewasa akarnya akan memecahkan batang bambu sehingga dapat tumbuh bebas.

- Pencemaran lingkungan

Mengatasi pencemaran lingkungan dengan melakukan pengolahan limbah mangrove, ternak, dan sisa makanan menggunakan biogas yang merupakan sumber energi terbarukan dari proses penguraian bahan-bahan organik oleh mikroorganisme secara anaerob. Energi dari biogas dapat digunakan sebagai bahan bakar, menghasilkan listrik, dan sisa hasil biogas dapat dibuat pupuk.

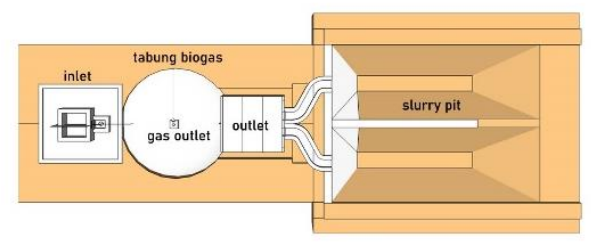

TAMPAK ATAS BIOGAS

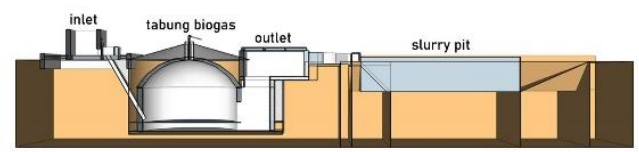

POTONGAN BIOGAS

Gambar 2. Tampak Atas Biogas dan Potongan Biogas Sumber: Penulis, 2021

Proses biogas dengan cara mencampurkan limbah dan air ke dalam bak pencampur dengan perbandingan 1:2. Limbah dialirkan menuju reaktor (digester) melalui saluran masuk (inlet) dan nantinya terbentuk gas metana dan karbon dioksida pada kubah biogas. Kemudian gas yang dihasilkan disalurkan menuju penampung gas dan dapat dipakai untuk menyalakan api kompor gas. Biogas dari penampung gas bisa digunakan pada generator biogas untuk kemudian menyalakan peralatan listrik. Sisa proses biogas dapat diolah dan digunakan sebagai pupuk kandang (SNI 7826, 2012).

Sedangkan upaya mengurangi pencemaran air dengan mengolah air limbah menjadi air yang dapat digunakan kembali. Biofilter merupakan sistem pengolahan air limbah dengan memanfaatkan bakteri untuk menguraikan polutan air limbah.

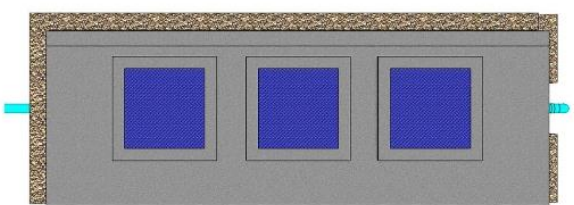

TAMPAK ATAS BIOFILTER

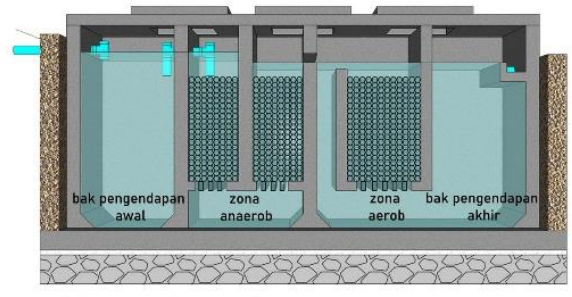

POTONGAN BIOFILTER

Gambar 3. Tampak Atas Biofilter dan Potongan Biofilter Sumber: Penulis, 2021

Air kotor dari dapur dan toilet masuk ke bak penampung air limbah, disalurkan ke bak pengendapan awal. Difilter dengan cara menggabungkan proses biofilter areob dan anaerob menuju ke bak pengendapan akhir dan menjadi air olahan yang dapat digunakan kembali untuk air toilet dan menyiram tanaman.

- Abrasi

Membuat alat pemecah ombak yaitu tetrapod. Tetrapod merupakan struktur beton dengan 4 sisi yang setiap sisinya seperti silinder. Berfungsi sebagai breakwater, melindungi dari erosi yang disebabkan gelombang laut. Pertahanan laut buatan ini dikombinasikan dengan pertahanan laut alami (mangrove) yang lebih sustainable yang disebut dengan tetrapot. Tetrapot dilubangi untuk 
membuat ruang sebagai sisipan pot biodigradable, tanah, dan ruang untuk akar mangrove tumbuh.

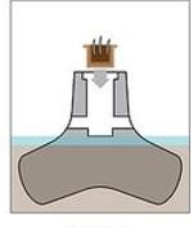

0 bulan

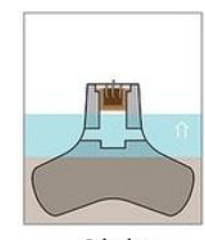

2 bulan

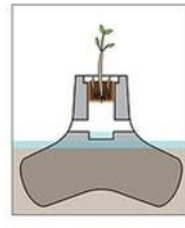

6 bulan

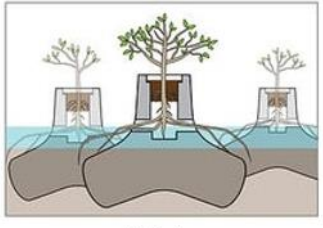

14 bulan

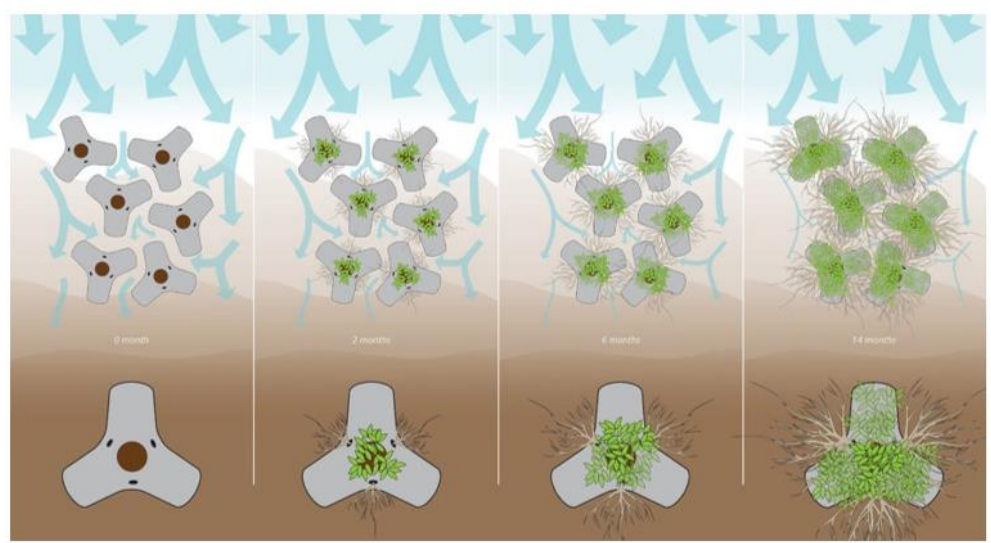

Gambar 4. Proses Tetrapot

Sumber: Diolah dari Google.com, 2021

Memasukkan pot yang berisi biji mangrove dan lapisan organik ke dalam tetrapod. Pada waktu 2 bulan ketika permukaan laut naik, sejumlah air akan dikumpulkan di bagian reses di dalam pot. Saat 6 bulan ketika pohon tumbuh, lapisan organik mulai terdekompos dengan akar mencapai ke bawah untuk air. Setelah 14 bulan akar pohon mulai keluar dari saluran dan mengelilingi pot selama periode waktu tertentu.

- Hama

Pemeliharaan mangrove memiliki tujuan jangka panjang untuk memastikan agar bibit-bibit mangrove bisa hidup dalam jangka waktu yang lama. Pemeliharaan dapat dilakukan dengan berbagai cara yaitu penyulaman, penyiangan, dan perlindungan tanaman dari kepiting.

\section{Tapak}

Kawasan terpilih berada di desa Bedono, kecamatan Sayung, Kabupaten Demak, Jawa Tengah. Desa Bedono merupakan salah satu desa yang berada di wilayah pesisir yang memiliki potensi alam yang untuk dikembangkan sebagai tempat wisata karena memiliki karateristik tersendiri yang mempunyai hutan mangrove, wisata air, dan kuliner olahan mangrove.

Namun selain memiliki banyak potensi, desa ini juga memiliki masalah terkait dengan pengembangan potensi antara lain permasalahan perencanaan wisata yang belum ada, masalah lingkungan yaitu adanya abrasi yang selama ini sudah menenggelamkan 6 dukuh. Beberapa rumah penduduk tergenang air dan ketinggian rumahnya berada di bawah permukaan tanah. Hal ini menunjukkan terjadinya penurunan permukaan tanah akibat abrasi. 


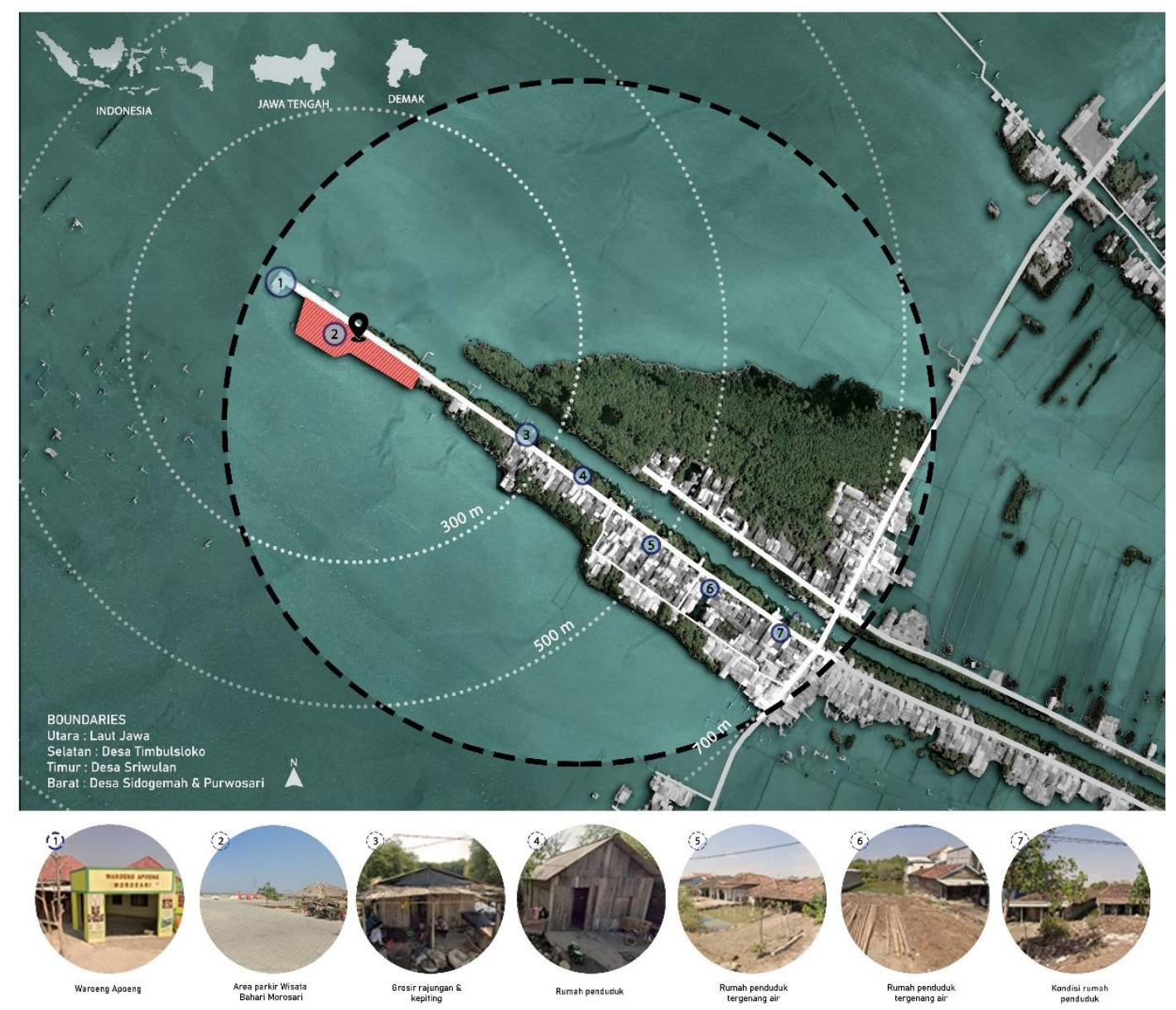

Gambar 5. Kawasan Desa Bedono

Sumber: Penulis, 2021

Kondisi mangrove di Demak yang mengalami kerusakan hutan mangrove mencapai 1.174 ha dari total luasan yang tertanam yaitu 4.203 ha. Jumlah tersebut tersebar di empat kecamatan yaitu Sayung, Karangtengah, Bonang, dan Wedung.

Tabel 1. Kondisi Mangrove di Kabupaten Demak

\begin{tabular}{lcc}
\hline \multicolumn{1}{c}{ Kecamatan } & Luas Hutan Mangrove (ha) & Luas Mangrove yang Rusak (ha) \\
\hline Sayung & $\mathbf{2 . 2 6 4}$ & $\mathbf{6 5 3}$ \\
\hline Wedung & 1.088 & 320 \\
\hline Bonang & 568 & 152 \\
\hline Karangtengah & 283 & 49 \\
\hline Total & $\mathbf{4 . 2 0 3}$ & $\mathbf{1 . 1 7 4}$ \\
\hline
\end{tabular}

Sumber: Data Dinas Kelautan dan Perikanan Demak, 2019

Jumlah mangrove yang dalam kondisi rusak seluas 1.174 ha dan 919 ha terancam rusak. Sisanya 2.110 ha merupakan kondisi mangrove yang masih bagus. Kerusakan mangrove tersebut mendorong laju abrasi pantai dan kecamatan Sayung menjadi wilayah pesisir yang mengalami tingkat abrasi terparah dan menyebabkan kerusakan hutan mangrove paling tinggi.

Abrasi mengakibatkan sekitar 600 ha daratan di Desa Bedono hilang dan menjadi lautan menyebabkan penduduk terpaksa merelokasi diri. Jumlah warga yang dulunya mencapai $4000 \mathrm{KK}$ sekarang tersisa 2000 KK atau sekitar 3511 jiwa. Dari jumlah penduduk tersebut sebesar 780 orang merupakan buruh tani tambak, 716 orang nelayan, dan sisanya bekerja sebagai buruh industri, pedagang, petani, dan pegawai (Badan Pusat Statistik Kabupaten Demak, 2019). 

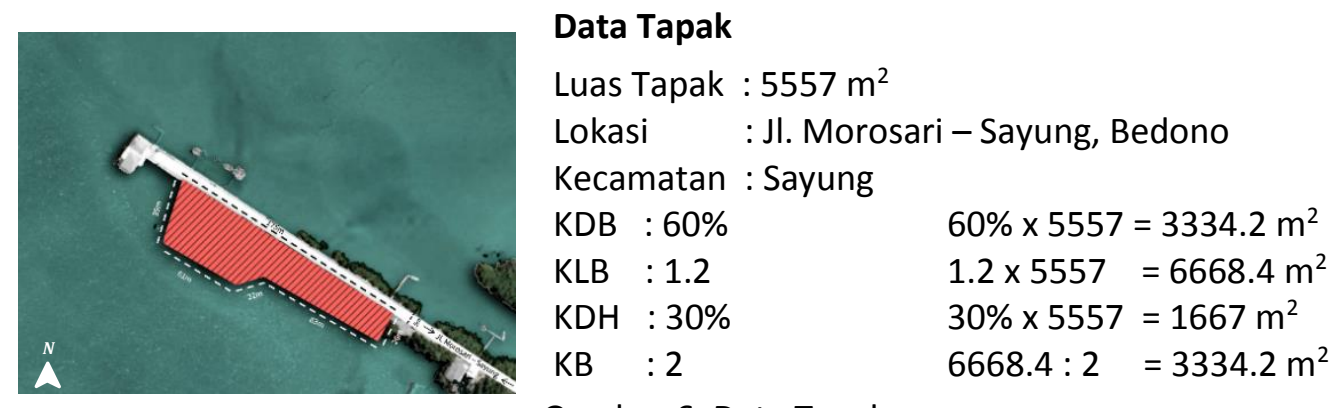

Gambar 6. Data Tapak

Sumber: Penulis, 2021

Lokasi tapak merupakan area parkir Wisata Bahari Morosari. Wisata Bahari Morosari merupakan tempat wisata yang menyajikan panorama pantai, kuliner laut, dan wisata air (perahu kayak, perahu kano, dan speed boat) yang menuju ke hutan mangrove. Namun kawasan ini tidak berkembang dan sepi pengunjung karena tidak difasilitasi sarana dan prasarana.

Akses menuju ke tapak dapat melalui jalur darat yang bisa dijangkau oleh kendaraan pribadi yang diparkir di area parkir dilanjutkan menggunakan sepeda menuju ke tapak. Serta perahu untuk akses pencapaian melalui jalur air.

\section{Program Kegiatan}

Berdasarkan permasalahan degradasi mangrove, untuk mewujudkan pelestarian hutan mangrove terdapat 4 program kegiatan utama pada pusat rekreasi dan edukasi pembudidayaan mangrove ini yaitu:

- Rekreasi

Kegiatan rekreasi dapat berupa kuliner, pertunjukan, melihat dan mengeksplorasi kawasan hutan mangrove. Pengunjung yang ingin melihat kawasan hutan mangrove dapat melalui jalur air dengan menaiki perahu untuk berkeliling dan berhenti untuk tracking ke dalam hutan mangrove. Tracking mangrove berupa lintasan jalan yang terletak di tengah hutan mangrove. Pengunjung yang ingin mengeksplorasi sendiri kawasan hutan mangrove dapat menyewa kano.

- Edukasi

Edukasi memiliki tujuan utama memberikan pengetahuan dan menyadarkan masyarakat tentang pentingnya ekosistem mangrove. Edukasi dibagi menjadi 2 yaitu edukasi aktif dan edukasi pasif. Edukasi aktif yaitu pengunjung dapat berinteraksi langsung dengan mangrove. Terdapat pembelajaran tentang mangrove mulai dari kelas budidaya mangrove yang nantinya pengunjung dapat menanam mangrove di kawasan mangrove, workshop untuk mengolah mangrove menjadi kerajinan tangan, bahan makanan, sabun cair, dan sebagainya. Mengedukasi secara pasif atau tidak terlibat langsung dengan mangrove dapat melalui koleksi buku dan galeri berisi informasi ekosistem mangrove. Kegiatan edukasi dapat dikolaborasikan dengan kegiatan rekreasi alam sehingga media edukasi yang dihadirkan dapat diwujudkan dengan lebih menyenangkan.

- Konservasi

Kegiatan melibatkan pengunjung untuk menanam dan memelihara mangrove yang dilakukan di kawasan mangrove tumbuh yaitu di hutan mangrove dan di dekat pemukiman warga. Penanaman mangrove menggunakan teknik REM dan ditanam di tetrapot.

- Penelitian

Penelitian melakukan riset dan observasi mengenai mangrove dan organisme lain yang ada di kawasan hutan mangrove. Mengidentifikasi jenis-jenis mangrove, mengetahui potensi dan manfaat mangrove, dan merumuskan strategi pengelolaan ekosistem mangrove yang berkelanjutan. 


\section{Gubahan Massa}

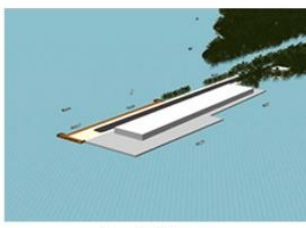

Basic Volume

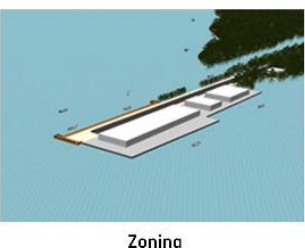

Zoning

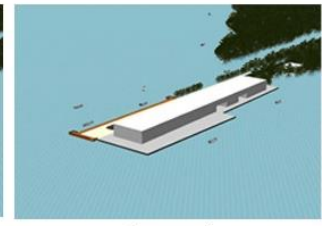

Connected

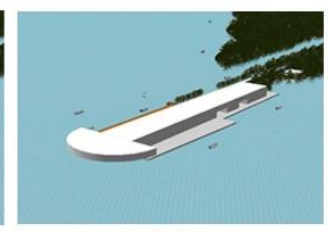

Semi-circle

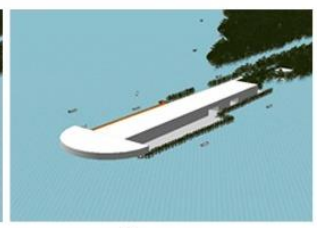

Mangrove

\section{Gambar 7. Proses Gubahan Massa}

Sumber: Penulis, 2021

Gubahan massa terbentuk berdasarkan analisis tapak dan kebutuhan dari program bangunan. Pembentukan massa diawali dengan mengikuti bentuk tapak yang memanjang. Lantai dasar massa dibagi menjadi 3 sebagai pemisah program yang sifatnya privat (utilitas dan kantor) dan publik (fungsi utama). Selanjutnya memberikan massa tingkat untuk menyatukan ketiga massa dan penambahan massa di laut berbentuk setengah bulat, supaya angin berbelok dan berubah arah mengikuti bentuk massa yang bulat. Mengakibatkan kecepatan angin menurun, sehingga meminimalisir angin kencang dari arah laut. Pada sekeliling tapak diletakkan tetrapot mangrove 3 lapis. Berdasarkan arah angin dan arus ombak paling kuat maka tetrapot diletakkan di sisi barat tapak sebagai pemecah ombak.

\section{Hasil Desain}

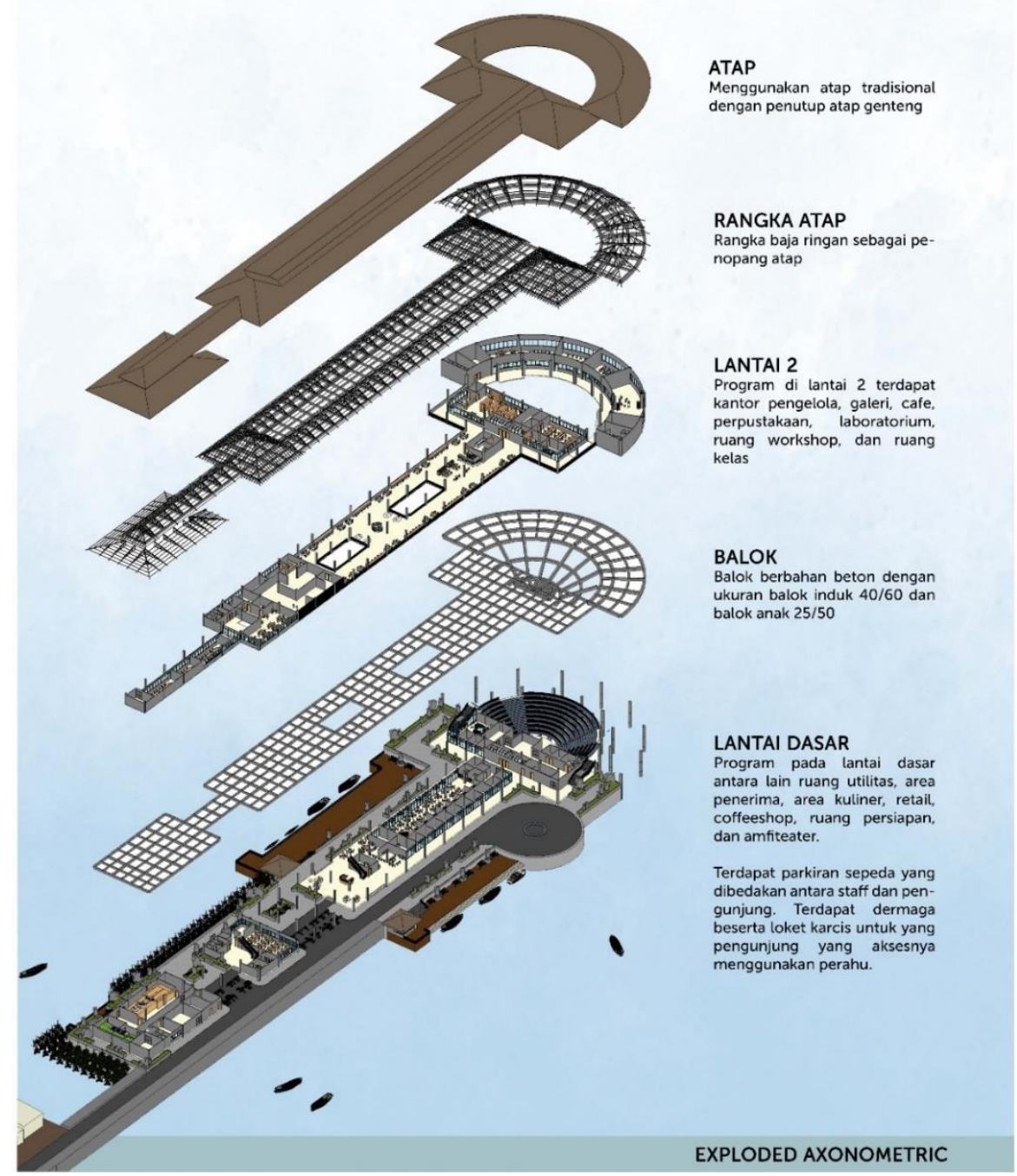

Gambar 8. Exploded Axonometric

Sumber: Penulis, 2021 
Pada lantai dasar dibedakan menjadi 3 menurut fungsinya yaitu utilitas, kantor, dan fungsi utama. Pada utilitas terdapat area MEP dan pengolahan limbah yaitu ruang biogas dan biofilter. Kantor yang sifatnya privat terdapat ruang staff. Serta fungsi utama yang sifatnya publik terdapat area penerima, area kuliner, retail, coffee shop, ruang persiapan, panggung, dan area outdoor berupa amfiteater di atas air. Program di lantai 2 terdapat kantor pengelola, galeri, kafe, perpustakaan, laboratorium, ruang workshop, dan ruang kelas.

Daya tarik utama adalah kawasan hutan mangrove yang dapat dicapai dari bangunan utama menggunakan perahu. Pengunjung dapat mengamati hutan mangrove dan turun di tracking mangrove untuk berkeliling ke dalam hutan mangrove. Pada kawasan hutan mangrove pengunjung dapat menanam bibit mangrove dengan arahan yang sudah diberikan terlebih dahulu di kelas budidaya mangrove.

Fasad dibuat dengan banyak bukaan untuk pengudaraan alami dan mengoptimalkan view ke arah laut. Pada fasad lantai 2 menggunakan panel kayu untuk memberikan kesan lokal dan kuat terhadap kondisi iklim. Atap menggunakan atap tradisional dengan rangka atap baja ringan sebagai penopang atap dan penutup atap genteng. Penghijauan pada tapak dengan tanaman yang ditanam di dalam pot sehingga tetap ada penghijauan di tapak yang mengalami perkerasan.

\section{Perspektif}
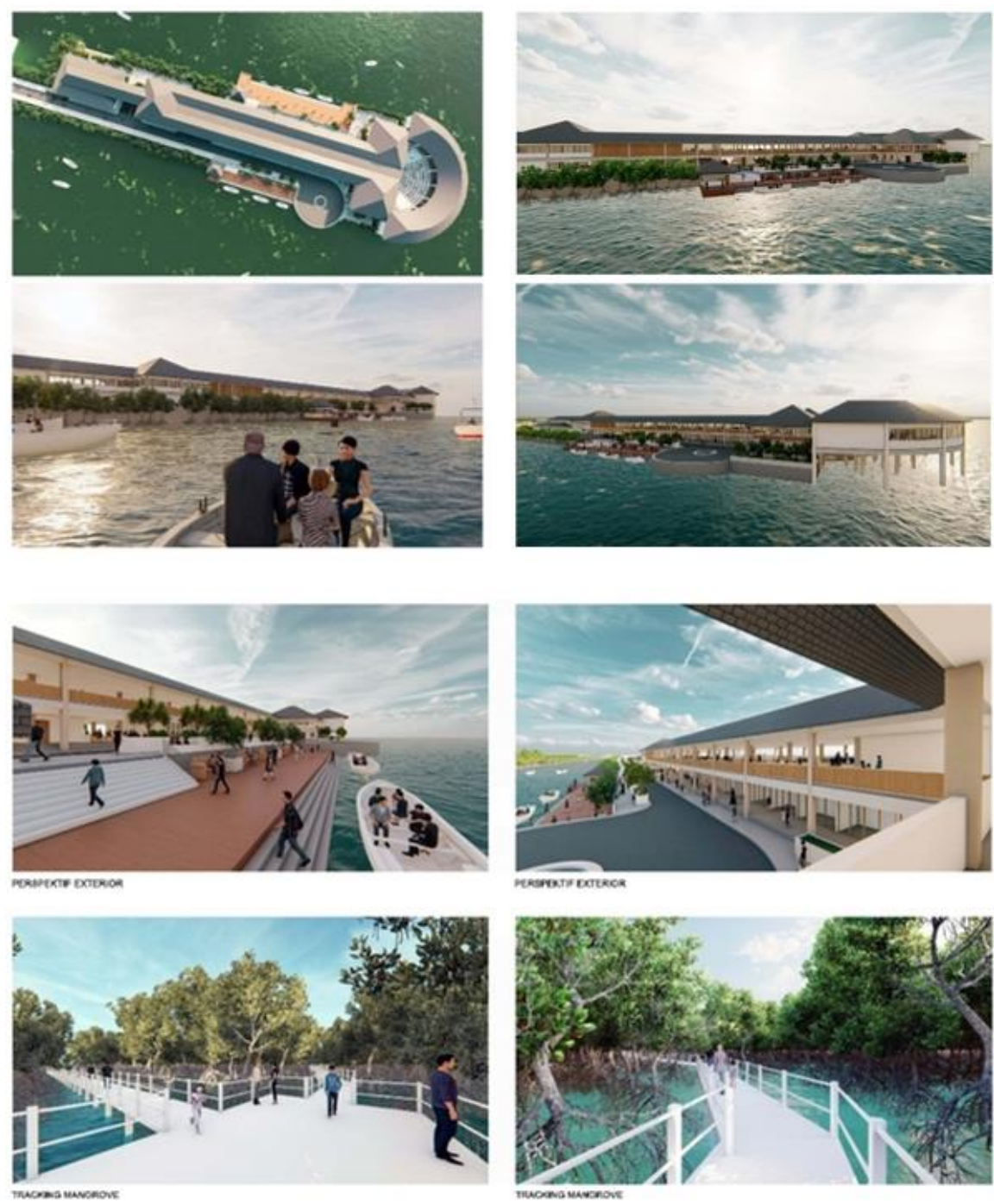

Gambar 9. Perspektif Eksterior

Sumber: Penulis, 2021 

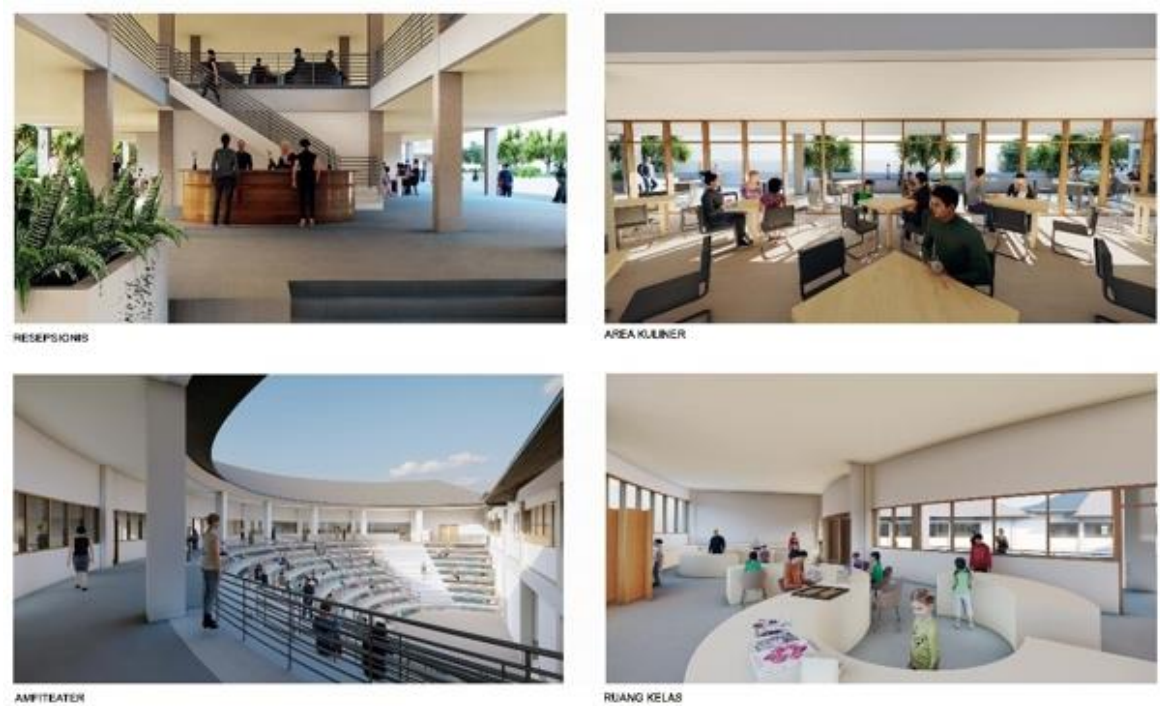

Gambar 10. Perspektif Interior

Sumber: Penulis, 2021

\section{KESIMPULAN DAN SARAN \\ Kesimpulan}

Degradasi mangrove yang terjadi di desa Bedono, Kabupaten Demak, Jawa Tengah akibat abrasi sebagai masalah utama dan penyebab lainnya yaitu penebangan liar, konversi lahan, pencemaran lingkungan, dan hama. Melalui arsitektur menjawab permasalahan dengan program dan strategi yang dapat melindungi dan mempertahankan hutan mangrove yang ada saat ini.

Berdasarkan permasalahan tersebut, menciptakan pusat rekreasi dan edukasi pembudidayaan mangrove yang memiliki empat program utama yaitu rekreasi, edukasi, konservasi, dan penelitian. Rekreasi dan edukasi mangrove dihadirkan melalui tracking mangrove, kelas budidaya mangrove, dan kegiatan menanam mangrove yang dilakukan di kawasan hutan mangrove sehingga pengunjung mendapatkan pengalaman berinteraksi langsung dengan mangrove.

Pemulihan dan pengelolaan hutan mangrove dengan memberikan strategi sebagai solusi untuk melestarikan hutan mangrove yang rusak dan terancam. Strategi tersebut ialah melakukan penanaman, penyuluhan, dan pemeliharaan mangrove, mengolah limbah dengan menggunakan biogas dan biofilter, serta membuat tetrapot mangrove sebagai alat pemecah ombak. Penempatan strategi-strategi tersebut diletakkan pada bangunan serta kawasan hutan mangrove.

\section{Saran}

Perancangan pusat rekreasi dan edukasi pembudidayaan mangrove diharapkan meningkatkan pengetahuan masyarakat akan pentingnya melestarikan mangrove dan perlu adanya sosialisasi program atau penyuluhan konservasi secara kontinyu kepada masyarakat. Hal ini dilakukan agar masyarakat mengetahui dan dapat berpartisipasi dalam kegiatan melestarikan mangrove.

Selain itu, diharapkan pemerintah setempat mengambil tindakan yang intensif agar dapat menanggulangi terjadinya masalah kerusakan hutan mangrove. Serta dibutuhkan suatu kebijakan tegas dalam menerapkan aturan pemanfaatan sumberdaya mangrove.

\section{REFERENSI}

Badan Pusat Statistik Kabupaten Demak. (2019). Kecamatan Sayung dalam Angka 2019. Demak: Badan Pusat Statistik Kabupaten Demak.

Barus, Agape Robi. (2015). Pengertian Edukasi, Macam-macam Edukasi dan Manfaatnya Bagi Manusia. Retrieved April 24, 2021, from http://www.edukasinesia.com/2015/10/pengertianedukasimacam-macam_13.html. 
Noor, Y. R., Khazali, M., \& Suryadiputra, I. N. N. (2012). Panduan Pengenalan MANGROVE di Indonesia. Bogor: Ditjen PHKA dan Wetlands International Indonesia Programme.

Rahadian, A., Prasetyo, L. B., Setiawan, Y., \& Wikantika, K. (2019). A Historical Review of Data and Information of Indonesian Mangroves Area. Media Konservasi, 24(2), 163-178.

SNI 7826. (2012). Unit Penghasil Biogas dengan Tangki Pencerna (Digester) Tipe Kubah Tetap dari Beton. Jakarta: Badan Standardisasi Nasional - BSN.

Sutrisno. (2005). Revolusi Pendidikan di Indonesia: Membedah Metode dan Teknik Pendidikan Berbasis Kompetensi. Yogyakarta: AR Ruzz Media. 